\title{
Key European guidelines for the diagnosis and management of patients with phenylketonuria
}

\author{
Francjan J van Spronsen, Annemiek MJ van Wegberg, Kirsten Ahring, Amaya Bélanger-Quintana, Nenad Blau, Annet M Bosch, Alberto Burlina, \\ Jaime Campistol, Francois Feillet, Maria Giżewska, Stephan C Huijbregts, Shauna Kearney, Vincenzo Leuzzi, Francois Maillot, Ania C Muntau, \\ Fritz K Trefz, Margreet van Rijn, John H Walter, Anita MacDonald
}

We developed European guidelines to optimise phenylketonuria (PKU) care. To develop the guidelines, we did a literature search, critical appraisal, and evidence grading according to the Scottish Intercollegiate Guidelines Network method. We used the Delphi method when little or no evidence was available. From the 70 recommendations formulated, in this Review we describe ten that we deem as having the highest priority. Diet is the cornerstone of treatment, although some patients can benefit from tetrahydrobiopterin (BH4). Untreated blood phenylalanine concentrations determine management of people with PKU. No intervention is required if the blood phenylalanine concentration is less than $360 \mu \mathrm{mol} / \mathrm{L}$. Treatment is recommended up to the age of 12 years if the phenylalanine blood concentration is between $360 \mu \mathrm{mol} / \mathrm{L}$ and $600 \mu \mathrm{mol} / \mathrm{L}$, and lifelong treatment is recommended if the concentration is more than $600 \mu \mathrm{mol} / \mathrm{L}$. For women trying to conceive and during pregnancy (maternal PKU), untreated phenylalanine blood concentrations of more than $360 \mu \mathrm{mol} / \mathrm{L}$ need to be reduced. Treatment target concentrations are as follows: 120-360 $\mu \mathrm{mol} / \mathrm{L}$ for individuals aged 0-12 years and for maternal PKU, and 120-600 $\mu \mathrm{mol} / \mathrm{L}$ for non-pregnant individuals older than 12 years. Minimum requirements for the management and follow-up of patients with PKU are scheduled according to age, adherence to treatment, and clinical status. Nutritional, clinical, and biochemical follow-up is necessary for all patients, regardless of therapy.

\section{Introduction}

Phenylketonuria (PKU) is a rare autosomal recessive inborn error of phenylalanine metabolism with an estimated frequency in Europe of 1 in 10000 newborn babies (panels 1 and 2). ${ }^{1}$ Deficiency of the hepatic-based enzyme phenylalanine hydroxylase (PAH) results in a complete or partial inability to convert phenylalanine (from the diet or derived from catabolism of proteins in the body) to tyrosine (figure 1 ), ${ }^{2}$ which can lead to high blood phenylalanine concentrations that cross the bloodbrain barrier causing detrimental effects on brain development and function. Available treatments aim to decrease the blood phenylalanine concentration, which is considered the surrogate marker for brain phenylalanine concentrations. Nevertheless, the precise pathophysiology of PKU remains unclear (figure 2). ${ }^{3}$ Clinically, untreated PKU is characterised by irreversible intellectual disability, microcephaly, seizures, aberrant behaviour, psychiatric symptoms, motor disturbances, and eczematous rash. When diagnosed by newborn screening and treated immediately, patients essentially show normal development, although neuropsychological deficits and behavioural and social issues can occur. ${ }^{2,5}$ Dietary treatment consists of a low-phenylalanine diet, restrictive in natural protein combined with phenylalanine-free L-aminoacid supplements and low protein foods. Some patients with PKU respond to tetrahydrobiopterin (BH4), a naturally occurring essential cofactor for PAH that acts as a pharmaceutical chaperone (prescribed as sapropterin dihydrochloride), decreases blood phenylalanine concentrations and increases dietary phenylalanine tolerance. $^{2}$ In some (mainly nonEuropean) countries, casein glycomacropeptide or large neutral aminoacids are used for treatment, but both
Panel 1: Information on genetics and pathophysiology of phenylketonuria (PKU)

\section{Genetics of PKU $^{2}$}

PKU is caused by mutations in the gene encoding phenylalanine hydroxylase (PAH). The PAH gene is located on chromosome 12 (region q22-24.1) consisting of 13 exons and 12 introns, in total covering $100 \mathrm{~kb}$ of genetic data. More than 950 mutations in the gene encoding PAH (BIOPKU database) are known to be associated with PAH deficiency. Most of the mutations are missense, usually resulting in protein misfolding or impairment of catalytic functions. The prevalence of PKU shows considerable geographic variation; in Europe it occurs in one in 10000 newborn babies, with a higher rate in some countries, such as Ireland and Turkey, but a very low rate in Finland.

Phenylalanine hydroxylase ${ }^{2}$

Phenylalanine is hydroxylated by $\mathrm{PAH}$, necessitating tetrahydrobiopterin (BH4) as a cofactor, with iron and oxygen. The structure of PAH is a tetramer. During the hydroxylation of phenylalanine, $\mathrm{BH} 4$ is oxidised to a 4a-hydroxy intermediate, which is subsequently regenerated to $\mathrm{BH} 4$ by the enzymes carbinolamie-4a-dehydratase and dihydropteridine reductase. $\mathrm{BH} 4$ is synthesised from guanosine triphosphate (GTP) by three additional enzymes: GTP cyclohydrolase I, 6-pyruvoyl-tetrahydropterin synthase, and sepiapterin reductase. Variants in the genes encoding the enzymes involved in $\mathrm{BH} 4$ metabolism result in $\mathrm{BH} 4$ deficiency, mostly treated with $\mathrm{BH} 4$ and neurotransmitter precursors. Some patients with PAH deficiency also respond to $\mathrm{BH} 4$. This response is referred to as $\mathrm{BH} 4$ responsiveness.
Lancet Diabetes Endocrinol 2017 Published Online January 9, 2017 http://dx.doi.org/10.1016/ S2213-8587(16)30320-5

Department of Dietetics (M van Rijn PhD), Division of Metabolic Diseases, (Prof F) van Spronsen MD, A M J van Wegberg MSc), Beatrix Children's Hospital, University Medical Center Groningen, University of Groningen, Groningen, Netherlands; Department of PKU, Kennedy Centre, Copenhagen University Hospital, Glostrup, Denmark (K Ahring MSc); Metabolic Diseases Unit, Department of Pediatrics, Hospital Ramony Cajal, Madrid, Spain

(A Bélanger-Quintana MD); University Children's Hospital, Dietmar-Hoppe Metabolic Centre, Heidelberg, Germany (Prof N Blau PhD, Prof F KTrefz MD); University Children's Hospital Zurich, Zurich, Switzerland (Prof N Blau); Department of Paediatrics, Division of Metabolic Disorders, Academic Medical Centre, University Hospital of Amsterdam, Amsterdam, Netherlands (A M Bosch MD); Division of Inherited Metabolic Diseases, Department of Paediatrics, University Hospital of Padova Padova, Italy (A Burlina MD); Neuropaediatrics Department, Hospital Sant Joan de Déu, University of Barcelona, Barcelona, Spain (Prof J Campistol MD); Department of Pediatrics, Hôpital d'Enfants Brabois, CHU Nancy, Vandoeuvre les Nancy, France (Prof F Feillet MD); Department of Pediatrics, Endocrinology, Diabetology, Metabolic Diseases and Cardiology of the Developmental Age, Pomeranian Medical University, Szczecin, Poland (M Giżewska MD); Department of Clinical Child and Adolescent Studies-Neurodevelopmental Disorders, Faculty of Social 
Panel 2: Definitions of genetics and pathophysiology of phenylketonuria (PKU)

\section{Executive functioning}

Executive functioning describes cognitive processes that regulate behaviour; examples are inhibitory control, working memory, and cognitive flexibility.

\section{High-risk pregnancy}

A pregnancy that threatens the health or life of the mother or her fetus.

\section{Hyperphenylalaninaemia}

Any blood phenylalanine concentration more than $120 \mu \mathrm{mol} / \mathrm{L}$.

\section{Late treated or untreated adults}

Late diagnosis refers to children diagnosed between ages 3 months and 7 years ( $\geq 3$ months to $<7$ years). Untreated refers to patients who are untreated at age 7 years or older.

\section{Maternal PKU syndrome}

The teratogenic effects of elevated maternal phenylalanine levels during pregnancy to the fetus.

\section{Phenylalanine tolerance}

The amount of phenylalanine ( $\mathrm{mg} / \mathrm{kg}$ per day or $\mathrm{mg}$ per day) that maintains plasma phenylalanine concentrations within the target range. This amount might also be described as natural protein tolerance expressed as g per day, taking a phenylalanine content in natural protein as $50 \mathrm{mg}$ of phenylalanine per gram of natural protein.

\section{Protein requirements}

The lowest level of dietary protein intake that will balance the loss of nitrogen from the body, and thus maintain the body protein mass in a person at energy balance with modest levels of physical activity.

Protein substitutes (phenylalanine-free L-aminoacid supplements and low phenylalanine glycomacropeptide protein)

Protein replacements or substitutes are essential in treatment of PKU to prevent protein deficiency and optimise metabolic control. Protein substitutes are mainly sourced from phenylalanine-free L-aminoacid supplements and less commonly from low phenylalanine glycomacropeptide.

\section{$\mathrm{BH} 4$}

Cofactor of phenylalanine hydroxylase. $\mathrm{BH} 4$ also acts as a chaperone protein in some patients who are deficient in phenylalanine hydroxylase. $\mathrm{BH} 4$ is a cofactor of tyrosine and tryptophan hydroxylase and has a role in the conversion of $\mathrm{L}$-arginine to nitric oxide by nitric oxide synthases.

\section{BH4 deficiencies}

Defects in $\mathrm{BH} 4$ metabolism (either synthesis or turnover) result in a deficiency of BH4. These include three known defects for synthesis and two for regeneration (see also phenylalanine hydroxylase in panel 1).

\section{Potential BH4 responsiveness}

More than $30 \%$ reduction in blood phenylalanine in a $\mathrm{BH} 4$ loading test or two $\mathrm{BH} 4$-responsive mutations. $\mathrm{BH} 4$ responsiveness should be proven in a treatment trial adjusting the $\mathrm{BH} 4$ dosing, natural protein intake, and phenylalanine-free $\mathrm{L}$-aminoacid supplement.

\section{$\mathrm{BH} 4$ responsiveness}

In this Review we defined $\mathrm{BH} 4$ responsiveness as an increase of $100 \%$ or more in natural protein or improved biochemical control ( $>75 \%$ of phenylalanine levels in target range), or both, on a dose of $\mathrm{BH} 4$ that ranges between $1-20 \mathrm{mg} / \mathrm{kg}$ bodyweight (with a maximum dose of 1000 or $1400 \mathrm{mg}$ per day in some countries). safety and efficacy of these treatment strategies need further study. ${ }^{2}$

PKU management differs across Europe, with various local and national guidelines. A need exists for more standardised management tailored for optimal outcomes. ${ }^{6,7}$ The development of these European guidelines was driven both by health professionals and the patient organisation European Society for Phenylketonuria and Allied Disorders Treated as Phenylketonuria (ESPKU) ${ }^{7-9}$ Generally, guidelines should result in measurable improvements in patient care, ${ }^{10,11}$ consistent, high-quality treatment without inequity, and awareness of rare diseases. ${ }^{12}$ Here we report on the development of European PKU guidelines by 19 European PKU experts, and we highlight ten clinical recommendations (out of a total of 70 ) that we deem as having the highest priority for implementation. The key recommendations were based on the best available evidence for management of PKU that would achieve optimal clinical and neuropsychological outcomes without overtreatment and unnecessary costs.

\section{Guideline development}

The scientific advisory committee of the ESPKU was tasked with organising a group of European PKU experts. 19 health professionals were invited on the basis of their experience and expertise rather than nationality; one of them declined and one resigned for personal reasons. The 17 professionals included the following: paediatric and adult metabolic physicians, a paediatric neurologist, a biochemist, metabolic dietitians, neuropsychologists, and psychologists. They were divided into five working groups on (1) nutritional treatment and biochemical or nutritional follow-up (Working Group A); (2) neurocognitive outcomes including imaging (Working Group B); (3) psychosocial outcome, and adherence (Working Group C); (4) adult and maternal PKU, and late diagnosis of PKU and untreated PKU (Working Group D); and (5) diagnosis of PKU including treatment initiation and drugs in PKU (Working Group E). The working groups were supported by a project assistant and guidelines leader. We consulted an obstetrician for maternal PKU. We developed the guidelines between October, 2012, and December, 2015.

We developed the guidelines with the Appraisal of Guidelines, Research, and Evaluation in Europe method. We did the literature search, critical appraisal, and evidence grading according to the Scottish Intercollegiate Guidelines Network (SIGN) method (version 2011) using eight levels of evidence being transferred into grades of recommendations (from A [highest] to D [lowest], with an extra recommendation for so-called good practice points that are not based on any evidence).

All working groups defined key questions, after which they searched the published work for relevant papers with the help of the project assistant. All working groups and plenary sessions, to discuss as adequately as possible the statements without enough evidence, 
were facilitated by the guidelines leader or project assistant, or both. We sent a concept of the full guidelines worldwide to 14 external consultants (physicians and dietitians or nutritionists) and the board of the ESPKU. Further data about the process (including the questions for each of the key recommendations reached) are shown in the appendix.

\section{Guidelines}

\section{Overview}

The main topics of these guidelines are (1) diagnosis, treatment initiation, and treatment duration; (2) treatment targets; (3) practical issues in dietary and BH4 treatment; (4) follow-up; and (5) special conditions (maternal PKU; late PKU diagnosis and untreated PKU). In the final section, we discuss the future goals of PKU management. Panel 3 lists the ten key statements arising from these main topics. Some aspects of this Review are lacking a discussion in depth in part related to the length of the paper but also in part related to a lack of evidence. Where this is the case it is stated.

\section{Diagnosis and treatment initiation and duration}

Most of the statements on diagnosis and classification are experience-based rather than evidence-based. ${ }^{2} \mathrm{PAH}$ deficiency is usually classified as mild, moderate, or severe (also referred to as classic) PKU. This classification is commonly based on the highest untreated blood phenylalanine concentration following a clinical diagnosis or at newborn screening. However, blood samples for newborn screening might be collected before infants have achieved their peak phenylalanine concentration without treatment. Since this sample collection time limits the use of the traditional classification for severity, a new classification is proposed on the basis of whether patients with $\mathrm{PAH}$ deficiency-to maintain blood phenylalanine concentrations in the recommended range-do not need treatment, or require dietary intervention, or $\mathrm{BH} 4$, or both.

Newborn screening for PKU meets all accepted screening criteria including cost-benefit ratio. ${ }^{13}$ Therefore, newborn screening for PKU should be done in every European country. This screening not only needs a robust infrastructure in which blood is taken from all newborn babies within a few days of birth, but also a well equipped laboratory that can manage and assess bloodspots efficiently. Low-income countries might consider using newborn screening laboratory facilities of another country as a possible option.

In any child referred for hyperphenylalaninaemia, BH4 deficiencies and liver disease should be excluded, as these require other treatment strategies. Before starting treatment or doing a BH4 challenge, samples for pterins in blood and urine and dihydropteridine reductase activity in dried blood spots are taken. Additionally, a $24 \mathrm{~h}$ BH4 loading test might be useful, especially if time until receipt

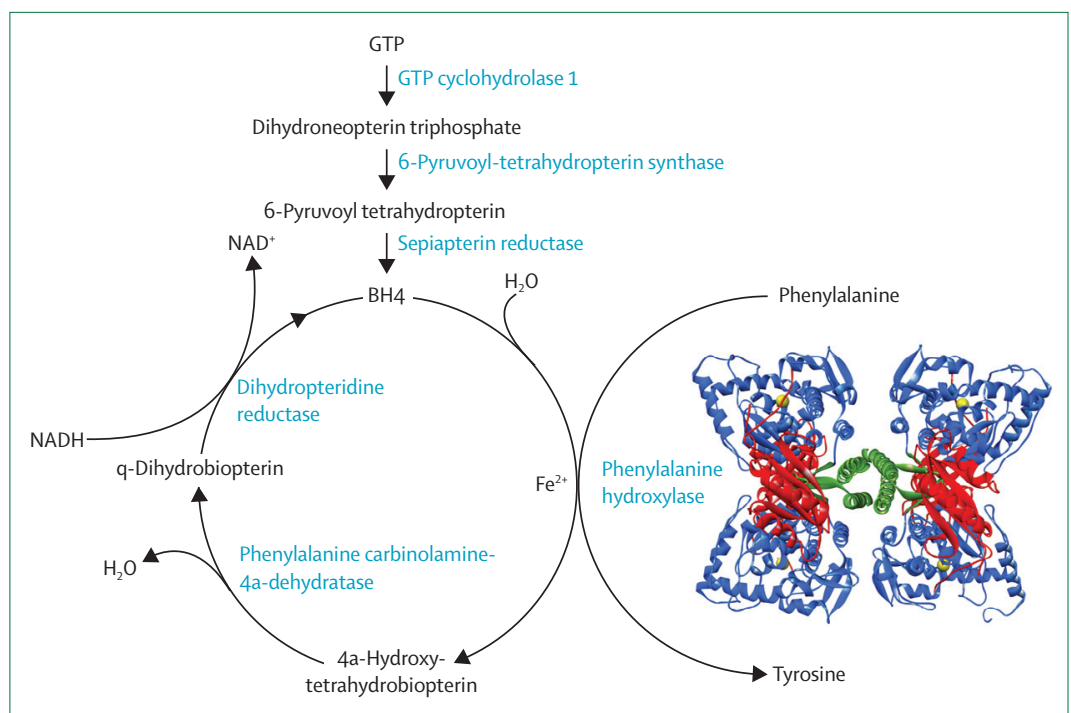

Figure 1: Phenylalanine hydroxylating system ${ }^{2}$

$\mathrm{BH} 4=$ tetrahydrobiopterin. GTP=guanosine triphosphate.

of laboratory results of pterins and dihydropteridine reductase activity is an issue. BH4 deficiencies should be considered in any child with neurological problems of unknown origin with even only slightly increased blood phenylalanine concentrations.

In patients with PKU, every 4 week delay in starting treatment results in a decline of approximately four intelligence quotient (IQ) points, ${ }^{14}$ which underscores the knowledge that neurological damage starts early after birth. Therefore, the organisation of newborn screening and referral to PKU centres is strongly advocated so that treatment is started no later than 10 days of age.

A clear consensus exists that patients with untreated blood phenylalanine concentrations of less than $360 \mu \mathrm{mol} / \mathrm{L}$ do not require treatment and that treatment is required in those with phenylalanine concentrations of more than $600 \mu \mathrm{mol} / \mathrm{L}$. The necessity of treatment for untreated phenylalanine concentrations between $360 \mu \mathrm{mol} / \mathrm{L}$ and $600 \mu \mathrm{mol} / \mathrm{L}$ is less clear; ${ }^{15,16}$ only Weglage and colleagues ${ }^{17}$ have adequately studied patients with untreated phenylalanine concentrations within this range and suggested it was safe. However, in that study only seven of the 31 patients had an untreated phenylalanine concentration of more than $500 \mu \mathrm{mol} / \mathrm{L}$, and on such evidence we consider it inappropriate to recommend that untreated phenylalanine concentrations of 360-600 $\mathrm{\mu mol} / \mathrm{L}$ are safe. ${ }^{17}$ Therefore, we advise treatment for any child with untreated phenylalanine concentrations of more than $360 \mu \mathrm{mol} / \mathrm{L}$. This advice is not based on conclusive evidence and further data are still required for a definitive recommendation.

With regards to the duration of treatment, we advise treatment until age 12 years in individuals with untreated phenylalanine concentrations between $360 \mu \mathrm{mol} / \mathrm{L}$ and
Sciences, Leiden University, Leiden, Netherlands (SC Huijbregts PhD); Clinical Psychology Department (S Kearney MSc) and Dietetic Department

(Prof A MacDonald PhD), Birmingham Children's Hospital, Birmingham, UK; Department of Pediatrics, Child Neurology and Psychiatry, Sapienza University of Rome, Rome, Italy (Prof V Leuzzi MD); Internal Medicine Service, CHRU de Tours, François Rabelais University, Tours, France (F Maillot MD); University Children's Hospital, University Medical Center

Hamburg-Eppendorf, Hamburg, Germany (Prof A C Muntau MD); and Manchester Academic Health Sciences Centre, Central Manchester University Hospitals NHS Foundation Trust, Manchester, UK (Prof J HWalter MD)

Correspondence to: Prof Francjan J van Spronsen, Division of Metabolic Diseases, Beatrix Children's Hospital, University Medical Center Groningen, 9700 RB, Groningen, Netherlands f.j.van.spronsen@umcg.nl For more on the BIOPKU database see http://www.biopku.org/home/ pah.asp 


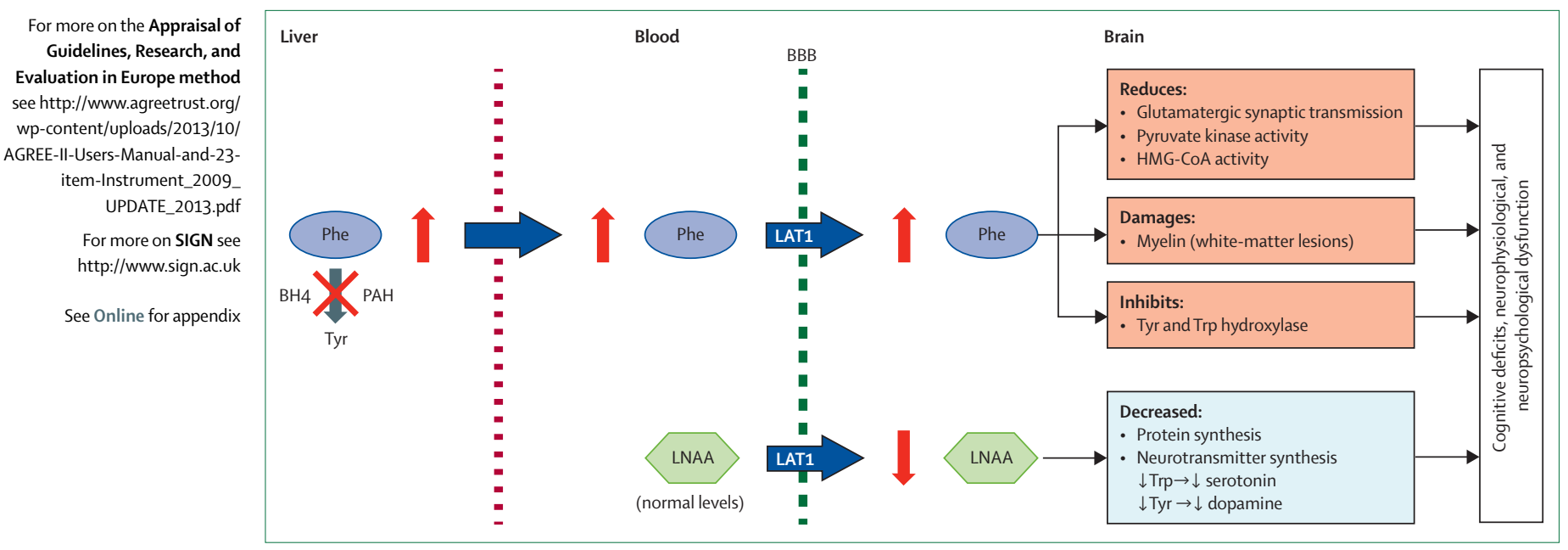

Figure 2: Pathophysiology of phenylketonuria

Summary of potential mechanisms of neurocognitive impairment by high phenylalanine concentrations. This figure shows the detrimental effects of high phenylalanine in the brain, as well as the effects of very low concentrations of LNAA in the brain. These low concentrations are the result of the effect of high blood phenylalanine concentrations on the transport of LNAA from blood to brain, even when the blood concentrations of LNAA are within the normal range. Reproduced with permission from Pediatrics, 126, 333-41, Copyright $\odot 2010$ by the AAP. ${ }^{4}$ Phe=phenylalanine. BBB=blood-brain barrier. LNAA=large neutral aminoacids. LAT1=L-type aminoacid carrier. BH4=tetrahydrobiopterin. HMG-CoA=3-hydroxy-3-methylglutaryl-coenzyme A. Tyr=tyrosine. Trp=tryptophan.

$600 \mu \mathrm{mol} / \mathrm{L}$, providing blood phenylalanine remains less than $600 \mu \mathrm{mol} / \mathrm{L}$ without treatment afterwards. We suggest this duration because of scarce and inconsistent evidence and the necessity for good metabolic control to retain cognitive function, especially during the first 12 years of life. ${ }^{18,19}$ In untreated women with phenylalanine concentrations of more than $360 \mu \mathrm{mol} / \mathrm{L}$, treatment is also required preconception and during pregnancy with the aim of reducing phenylalanine concentrations to less than $360 \mu \mathrm{mol} / \mathrm{L}$.

In patients with untreated phenylalanine concentrations of more than $600 \mu \mathrm{mol} / \mathrm{L}$, it is clearly unsafe to discontinue treatment before reaching adulthood (age 18 years), ${ }^{20-23}$ but the need to continue treatment during adulthood has been challenged. Evidence from the results of studies summarised in a systematic review show that in adults treated early (with treatment continued or discontinued) for PKU (usually $>600 \mu \mathrm{mol} / \mathrm{L}$ ), significant suboptimal outcomes occur compared with healthy individuals, including deficits in executive function, attention problems, decreased verbal memory, expressive naming and verbal fluency, mood, and social and emotional difficulties. ${ }^{4}$ Whether these suboptimal outcomes are because of suboptimal treatment during adulthood, adolescence, or even before is unclear. Adults treated early (treatment was both continued and discontinued) for PKU usually show a clear association between concurrent blood phenylalanine concentrations and certain aspects of brain function, brain metabolism, and differences in myelination, as summarised by van Spronsen and colleagues. ${ }^{24}$ Adult patients with PKU, who are no longer on a phenylalanine restricted diet, can experience neurological complications $s^{25}$ and vision $\operatorname{loss}^{26,27}$ that can improve or even reverse after reinstitution of treatment. ${ }^{25-27}$
In adults continuing treatment for PKU, results of health-related quality of life surveys suggest that this quality of life is normal, with an improvement of healthrelated quality of life in some patients who had returned to a low phenylalanine diet having discontinued PKU treatment. ${ }^{28,29}$ However, non-PKU generic health-related quality of life questionnaires are insensitive to the subtle negative effects of PKU, which has led to the development of a validated PKU-specific questionnaire (PKU-QOL). ${ }^{30,31}$

On the basis of these data, we advise treatment for life for patients with untreated phenylalanine concentrations of more than $600 \mu \mathrm{mol} / \mathrm{L}$, even though it is acknowledged that dietary management is associated with a substantial patient burden.

\section{Treatment targets}

Blood phenylalanine is the primary marker for guiding available treatments. ${ }^{18,19,32}$ Table 1 lists the studies that were included through use of the SIGN method to achieve the highest level of evidence available for the statements that describe age-related target ranges. For children up to the age of 12 years, the results of meta-analyses by Albrecht and colleagues ${ }^{32}$ and Waisbren and colleagues ${ }^{18}$ suggested safe upper target blood phenylalanine concentrations of $320 \mu \mathrm{mol} / \mathrm{L}^{32}$ and $420 \mu \mathrm{mol} / \mathrm{L}^{18}$ and Fonnesbeck and colleagues $^{19}$ indicated that a mean concentration of $400 \mu \mathrm{mol} / \mathrm{L}$ was associated with an increased risk of an IQ less than 85. Some evidence also exists that shows more favourable outcomes when the mean blood phenylalanine concentrations are less than $240 \mu \mathrm{mol} / \mathrm{L}$ rather than $360 \mu \mathrm{mol} / \mathrm{L}$ (mean age $<12$ years). ${ }^{41}$ Jahja and colleagues $^{41}$ reported a better neuropsychological task performance by patients with PKU when blood phenylalanine concentrations were less than $240 \mu \mathrm{mol} / \mathrm{L}$ than 
Panel 3: Key recommendations for patients with phenylketonuria (PKU)

The grades range from $\checkmark$ (no possibility to assess the level of evidence because of a lack of any published work on this issue) to as high as B. The key recommendations were either based on evidence (if level of evidence was A or B using the SIGN method) or by consensus (using the Delphi method) if the level of evidence was $C$ or $D$, or the so-called good practice points that are not based on any evidence if the level was $\checkmark$.

\section{Statement 1}

Grade of recommendation: $\checkmark$

To maintain blood phenylalanine concentrations in the recommended range, patients with phenylalanine hydroxylase (PAH) deficiency can be classified as either not requiring treatment, or requiring diet or tetrahydrobiopterin $(\mathrm{BH} 4)$, or both.

\section{Statement 2}

Grade of recommendation*: C

In the differential diagnosis of hyperphenylalaninaemia, of any degree, $\mathrm{BH} 4$ deficiencies should be excluded by measurement of pterins in blood or urine and dihydropteridine reductase activity in dried blood spot.

\section{Statement 3}

Grade of recommendation: $D / C$

Patients with untreated blood phenylalanine concentrations less than $360 \mu \mathrm{mol} / \mathrm{L}$ do not require treatment. Patients with untreated blood phenylalanine levels more than $360 \mu \mathrm{mol} / \mathrm{L}$ should be treated. Patients with untreated phenylalanine levels between $360 \mu \mathrm{mol} / \mathrm{L}$ and $600 \mu \mathrm{mol} / \mathrm{L}$ should be treated until the age of 12 years. Patients with untreated phenylalanine levels more than $600 \mu \mathrm{mol} / \mathrm{L}$ should be treated for life.

\section{Statement 4}

Grade of recommendation: $C$

All adults with PKU should have life-long, systematic follow-up in specialised metabolic centres, because of specific risks that might occur during adulthood.

\section{Statement 5}

Grade of recommendation: $B$

In treated patients with PKU up to the age of 12 years, target phenylalanine concentrations should be $120-360 \mu \mathrm{mol} / \mathrm{L}$.

\section{Statement 6}

Grade of recommendation: $D$

In treated patients with PKU aged 12 years or older, the target

phenylalanine concentrations should be $120-600 \mu \mathrm{mol} / \mathrm{L}$.

\section{Statement 7}

Grade of recommendation: $B$

In pregnant patients treated for PKU the target phenylalanine concetrations should be $120-360 \mu \mathrm{mol} / \mathrm{L}$.

\section{Statement 8}

Grade of recommendation: $B$

Women with untreated blood phenylalanine concentrations less than $360 \mu \mathrm{mol} / \mathrm{L}$ do not require treatment to lower blood phenylalanine before or during pregnancy.

\section{Statement 9}

Grade of recommendation: $\mathrm{C}$

An annual nutritional review is required for any patient who is on a prescribed low phenylalanine diet or is self-restricting high protein foods. Such review must include a clinical examination including the anthropometric parameters (weight, height, BMI). We also recommended that plasma aminoacids, plasma homocysteine or methylmalonic acid, haemoglobin, mean corpuscular volume, and ferritin are measured. All other micronutrients (vitamins and minerals including calcium, zinc, selenium) or hormones (parathyroid hormone) can be considered if clinically indicated.

\section{Statement 10}

Grade of recommendation: $\checkmark$

In patients younger than 12 years, when more than $50 \%$ of the phenylalanine concentrations are out of target range over a period of 6 months, consider: (1) increased frequency of blood phenylalanine monitoring and outpatient visits and re-education, (2) psychology consultation or social worker intervention, and (3) hospital admission. When around $100 \%$ of blood phenylalanine concentrations are out of target range over a period of 6 months and there are other signs of failure of adherence, such as lack of cooperation, clinic non-attendance, or unresolved issues outside PKU consider consultation with social services and child safeguarding measures.

*Level of evidence is chosen as C because of the high number of data notwithstanding that most included papers are of descriptive nature. patients with concentrations between $240 \mu \mathrm{mol} / \mathrm{L}$ and $360 \mu \mathrm{mol} / \mathrm{L}$ (mean age < 12 years); however, despite being statistically significant, differences of inhibitory control and cognitive flexibility, and motor control were not clinically significant.

Therefore, in view of the overall available evidence, we advise $360 \mu \mathrm{mol} / \mathrm{L}$ as the upper target phenylalanine blood concentration for the first 12 years of life. Data about adolescents and adults are scarce, necessitating further data collection within long-term international collaborative studies. Using the data shown in table 1, we advise an upper target phenylalanine blood concentration of $600 \mu \mathrm{mol} / \mathrm{L}$ for all individuals older than 12 years. This statement is different when compared to the upper target phenylalanine concentration of $360 \mu \mathrm{mol} / \mathrm{L}$ for adults with PKU, as advised by the American College of Genetics and Genomics. ${ }^{45}$ The upper target of $360 \mu \mathrm{mol} / \mathrm{L}$ is based on 
a meta-analysis with three starting conditions: measures of cognitive outcomes other than IQ are either used non-uniformly across studies or are too difficult to combine; IQ variation is not an important component of variation of bias; and the effect of historical (lifetime) and momentary phenylalanine concentrations after 6 years of age is seen as one factor only. ${ }^{19}$ We acknowledge the importance of this meta-analysis, ${ }^{19}$ and think that the bias due to variation in IQ measures and variation of individual IQ over time should not be underestimated. Additionally, the effect of the metabolic control on adult
IQ as a measure of neurocognitive outcome should not be overestimated, and in adulthood, the target phenylalanine concentration should be decided by the effect of phenylalanine concentrations in adult age.

As the absolute phenylalanine concentration is the most crucial factor in directing treatment, phenylalanine measurements should be robust. The accuracy of aminoacid analysers, high-performance liquid chromatography, and tandem mass spectrometry is well established, but phenylalanine concentrations from dried blood spots are 8-26\% lower than venous blood

\begin{tabular}{|c|c|c|c|c|}
\hline & Studied population & Measurement of Phe & Measured outcome & Conclusion \\
\hline $\begin{array}{l}\text { MRI studies* }+ \text { : Weglage } \\
\text { et al }(2001),{ }^{17} \text { Bick et al } \\
(1993),{ }^{33} \text { Kono et al }(2005),{ }^{34} \\
\text { Cleary et al }(1994),{ }^{35} \text { and } \\
\text { Manara et al }(2009)^{36}\end{array}$ & $\begin{array}{l}\text { Children, adolescents, and adults } \\
\text { with PKU; range of } n=2-77\end{array}$ & $\begin{array}{l}\text { Concurrent Phe, lifetime Phe, or Phe } \\
\text { during childhood }\end{array}$ & $\begin{array}{l}\text { White matter } \\
\text { alteration by } \\
\text { magnetic resonance } \\
\text { imaging }\end{array}$ & $\begin{array}{l}\text { No white matter changes when blood Phe concentrations } \\
\text { were }<300-600 \mu \mathrm{mol} / \mathrm{L}\end{array}$ \\
\hline Waisbren et al $(2007)^{18 *} \ddagger$ & $\begin{array}{l}\text { Meta-analysis of } 40 \text { studies } \\
\text { reported in } 40 \text { papers; } \\
3361 \text { patients with PKU aged } \\
0-31 \text { years }\end{array}$ & $\begin{array}{l}\text { (1) Phe concentrations during critical } \\
\text { period (birth to } 6 \text { or } 12 \text { years); and } \\
\text { (2) lifetime Phe }\end{array}$ & IQ & $\begin{array}{l}\text { (1) Phe range } 423-750 \mu \mathrm{mol} / \mathrm{L} \text { : each increase of } 100 \mu \mathrm{mol} / \mathrm{L} \\
\text { results in } 1 \cdot 3-3.1 \text { point reduction of IQ points; and ( } 2 \text { ) Phe } \\
\text { range } 394-666 \mu \mathrm{mol} / \mathrm{L} \text { : each increase of } 100 \mu \mathrm{mol} / \mathrm{L} \text { results in } \\
1.9-4.1 \text { point reduction of IQ points }\end{array}$ \\
\hline Fonnesbeck et al $(2013)^{19 *} \ddagger$ & $\begin{array}{l}\text { Meta-analysis of } 17 \text { studies } \\
\text { reported in } 21 \text { papers; } 432 \text { patients } \\
\text { with PKU aged 2-32 years }\end{array}$ & $\begin{array}{l}\text { (1) Phe concentrations during critical } \\
\text { period of age }<6 \text { years; ( } 2 \text { ) lifetime } \\
\text { Phe for age } \geq 6 \text { years; and } \\
\text { (3) IQ measurement concurrent with } \\
\text { Phe in both periods }\end{array}$ & $\begin{array}{l}\text { Probability of lower } \\
\text { IQ (<85); general } \\
\text { population } \\
\text { probability was } \\
\text { approximately } 15 \%\end{array}$ & $\begin{array}{l}\text { (1) Probability of IQ }<85 \text { during the critical period ( }<6 \text { years) is } \\
19 \% \text { with Phe concentrations of } 400 \mu \mathrm{mol} / \mathrm{L} \text { and } 30 \% \text { with } \\
\text { Phe concentration of } 600 \mu \mathrm{mol} / \mathrm{L} ;(2) \text { probability of historical } \\
\text { Phe concentrations during the non-critical period ( } \geq 6 \text { years) } \\
\text { to result in IQ }<85 \text { is } 14 \% \text { with Phe concentration of } \\
400 \mu \mathrm{mol} / \mathrm{L} \text { and } 20 \% \text { with Phe concentration of } 600 \mu \mathrm{mol} / \mathrm{L} \text {; } \\
\text { and (3) concurrently measured Phe was weakly correlated } \\
\text { with probability of low IQ }\end{array}$ \\
\hline Weglage et al $(2013)^{23 *}$ & $\begin{array}{l}28 \text { adult patients with PKU younger } \\
\text { than } 32 \text { years with a relaxed diet in } \\
\text { young adulthood, } 16 \text { adult patients } \\
\text { with PKU older than } 32 \text { years with a } \\
\text { relaxed diet from age } 10 \text { years, and } \\
46 \text { controls }\end{array}$ & Lifetime and concurrent Phe & $\mathrm{IQ}$ and $\mathrm{EF}$ & $\begin{array}{l}\text { Stable outcomes in 5-year interval for both groups. Older } \\
\text { group had lower IQ and poorer EF than younger group. IQ and } \\
\text { EF were inversely associated with lifetime Phe }\end{array}$ \\
\hline Diamond et al $(1997)^{37} \ddagger$ & $\begin{array}{l}37 \text { patients with PKU (0.5-7 years) } \\
\text { and } 86 \text { controls }\end{array}$ & $\begin{array}{l}\text { Concurrent Phe (defined as mean } \\
\text { Phe during a } 6 \text {-week period before } \\
\text { testing) }<360 \mu \mathrm{mol} / \mathrm{L} \text { and } \\
360-600 \mu \mathrm{mol} / \mathrm{L}\end{array}$ & $\mathrm{EF}$ & $\begin{array}{l}\text { Those with concurrent Phe of } 360-600 \mu \mathrm{mol} / \mathrm{L} \text { did less well } \\
\text { in EF tasks (working memory and inhibitory abilities) than } \\
\text { concurrent Phe }<360 \mu \mathrm{mol} / \mathrm{L} \text { and controls }\end{array}$ \\
\hline Leuzzi et al $(2004)^{38} \ddagger$ & $\begin{array}{l}14 \text { patients with PKU (mean age } \\
10 \cdot 8 \text { years, range } 8-13 \text { years) and } \\
14 \text { age-sex-IQ-SES-matched } \\
\text { controls (mean age } 10 \cdot 9 \text { years, } \\
\text { range } 8-13 \text { years) }\end{array}$ & $\begin{array}{l}\text { Lifetime Phe } \leq 400 \mu \mathrm{mol} / \mathrm{L}(\mathrm{n}=5) \\
\text { and }>400 \mu \mathrm{mol} / \mathrm{L}(\mathrm{n}=9)\end{array}$ & $\mathrm{EF}$ & $\begin{array}{l}\text { Patients with lifetime } \mathrm{Phe}>400 \mu \mathrm{mol} / \mathrm{L} \text { did worse than those } \\
\text { with lifetime } \mathrm{Phe} \leq 400 \mu \mathrm{mol} / \mathrm{L} \text { in all tests of } \mathrm{EF}\end{array}$ \\
\hline Huijbregts et al $(2002)^{39} \ddagger$ & $\begin{array}{l}67 \text { patients with PKU ( } 7-14 \text { years) } \\
\text { and } 73 \text { age-matched controls }\end{array}$ & $\begin{array}{l}\text { Concurrently measured } \\
\text { Phe } \leq 360 \mu \mathrm{mol} / \mathrm{L}(\mathrm{n}=29) \text { and } \\
>360 \mu \mathrm{mol} / \mathrm{L}(\mathrm{n}=38)\end{array}$ & $\begin{array}{l}\text { Neuropsychological } \\
\text { speed tests, } \\
\text { including tests of EF }\end{array}$ & $\begin{array}{l}\text { Those with concurrent Phe }>360 \mu \mathrm{mol} / \mathrm{L} \text { did significantly } \\
\text { worse in several tests regarding } \mathrm{EF} \text { than healthy controls. } \\
\text { Patients with concurrent Phe concentrations } \leq 360 \mu \mathrm{mol} / \mathrm{L} \text { did } \\
\text { not differ from controls and were significantly better than } \\
\text { patients with concurrent Phe concentrations }>360 \mu \mathrm{mol} / \mathrm{L}\end{array}$ \\
\hline $\begin{array}{l}\text { Schmidt et al }(1996)^{40} \ddagger \\
\text { (included in Albrecht et al } \\
{[2009]^{32 *} \ddagger \text { ) }}\end{array}$ & $\begin{array}{l}93 \text { patients with PKU ( } 61 \text { with } \\
\text { good metabolic control and } \\
32 \text { with poor metabolic control) } \\
\text { and } 60 \text { controls; mean age of both } \\
\text { groups was } 8.7 \text { years }\end{array}$ & $\begin{array}{l}\text { Mean concurrent Phe of cluster with } \\
\text { good metabolic control was } \\
240 \mu \mathrm{mol} / \mathrm{L}(\mathrm{n}=30) \text { and with poor } \\
\text { metabolic control was } 620 \mu \mathrm{mol} / \mathrm{L} \\
(\mathrm{n}=31)\end{array}$ & $\begin{array}{l}\text { Neuropsychological } \\
\text { speed tests, } \\
\text { including tests of EF }\end{array}$ & $\begin{array}{l}\text { Sustained attention and calculation speed of long-term } \\
\text { well-controlled children (from birth to age } 9 \text { years) were } \\
\text { vulnerable to high concurrent Phe concentrations, whereas } \\
\text { children with low concurrent concentrations could not } \\
\text { counterbalance the effects of long-term (from birth to age } \\
9 \text { years) poor dietary control }\end{array}$ \\
\hline Schmidt et al $(1996)^{40} \dagger$ & $\begin{array}{l}15 \text { patients with PKU ( } 17-24 \text { years) } \\
\text { and } 19 \text { controls ( } 18-24 \text { years) }\end{array}$ & $\begin{array}{l}\text { Phe measured at three timepoints } \\
\text { concurrently with assessed } \\
\text { outcomes; strict diet with aminoacid } \\
\text { supplement vs no diet }\end{array}$ & $\begin{array}{l}\text { Neuropsychological } \\
\text { speed tests, } \\
\text { including tests of EF; } \\
\text { tested three times } \\
\text { with intervals of } \\
4-5 \text { weeks }\end{array}$ & $\begin{array}{l}\text { Better neuropsychological task performance for patient group } \\
\text { on diet (mean Phe of } 630 \mu \mathrm{mol} / \mathrm{L} \text { [range } 280-966]) \text { vs patient } \\
\text { group off diet (mean Phe of } 1320 \mu \mathrm{mol} / \mathrm{L}[720-1800] \text { and } \\
1410 \mu \mathrm{mol} / \mathrm{L}[1040-2200] \text { ) }\end{array}$ \\
\hline
\end{tabular}

(Table 1 continues on next page) 


\begin{tabular}{|c|c|c|c|c|}
\hline & Studied population & Measurement of Phe & Measured outcome & Conclusion \\
\hline \multicolumn{5}{|c|}{ (Continued from previous page) } \\
\hline Jahja et al $(2014)^{41} \ddagger$ & $\begin{array}{l}64 \text { patients with PKU (mean age } \\
10 \cdot 8 \text { years; range } 6-15 \text { years) and } \\
73 \text { controls (mean age } 10.9 \text { years) }\end{array}$ & $\begin{array}{l}\text { Lifetime Phe of } \leq 240 \mu \mathrm{mol} / \mathrm{L}(\mathrm{n}=10) \\
240-360 \mu \mathrm{mol} / \mathrm{L}(\mathrm{n}=33) \text {; or } \\
\geq 360 \mu \mathrm{mol} / \mathrm{L}(\mathrm{n}=21) \text { concurrent Phe }\end{array}$ & $\begin{array}{l}\text { Neuropsychological } \\
\text { speed tests, } \\
\text { including tests of EF }\end{array}$ & $\begin{array}{l}\text { Patients with PKU aged } 6-15 \text { years with mean lifetime Phe } \\
\text { concentrations }<240 \mu \mathrm{mol} / \mathrm{L} \text { did better than those with mean } \\
\text { lifetime Phe concentrations between } 240-360 \mu \mathrm{mol} / \mathrm{L} \text {, and } \\
\text { those with lifetime Phe concentrations }>360 \mu \mathrm{mol} / \mathrm{L} \text { on } \\
\text { performed speed EF tasks }\end{array}$ \\
\hline ten Hoedt et al $(2011)^{42} \dagger$ & $\begin{array}{l}\text { Nine patients with PKU } \\
\text { (19-34 years), double-blind } \\
\text { randomly assigned crossover trial; } \\
\text { treatment arm duration of } 4 \text { weeks }\end{array}$ & $\begin{array}{l}\text { Mean Phe during treatment with } \\
\text { placebo capsules and Phe-containing } \\
\text { capsules }\end{array}$ & $\begin{array}{l}\text { IQ, mood, and } \\
\text { neuropsychological } \\
\text { speed tests, } \\
\text { including tests of EF }\end{array}$ & $\begin{array}{l}\text { Improved mood and neuropsychological task performance } \\
\text { with lower Phe concentrations (Phe } 709 \mu \mathrm{mol} / \mathrm{L} \text { [SD 322] for } \\
\text { placebo vs } 1259 \mu \text { mol/L [332] for experimental condition) }\end{array}$ \\
\hline Hoeksma et al $(2009)^{43 \dagger}$ & 16 patients with PKU (16-47 years) & $\begin{array}{l}\text { Phe measured concurrently with } \\
\text { outcome }\end{array}$ & $\begin{array}{l}\text { Cerebral protein } \\
\text { synthesis rate by } \\
\text { brain positron } \\
\text { emission } \\
\text { tomography studies }\end{array}$ & $\begin{array}{l}\text { Recommended Phe concentrations }<600-800 \mu \mathrm{mol} / \mathrm{L} \\
\text { (because plasma Phe concentrations }>600-800 \mu \mathrm{mol} / \mathrm{L} \\
\text { decreased cerebral protein synthesis rates) }\end{array}$ \\
\hline Sanayama et al $(2011)^{44} \dagger$ & $\begin{array}{l}40 \text { patients with PKU ( } 15-50 \text { years) } \\
\text { and } 30 \text { age-BMI-biological } \\
\text { data-matched controls }\end{array}$ & $\begin{array}{l}\text { Phe measured concurrently with } \\
\text { outcome }\end{array}$ & $\begin{array}{l}\text { Oxidative stress } \\
\text { markers, antioxidant } \\
\text { concentrations, and } \\
\text { enzyme activities in } \\
\text { erythrocytes }\end{array}$ & $\begin{array}{l}\text { Recommended Phe concentrations }<700-800 \mu \mathrm{mol} / \mathrm{L} \text { because } \\
\text { the oxidative stress changed greatly at } 700-800 \mu \mathrm{mol} / \mathrm{L}\end{array}$ \\
\hline \multicolumn{5}{|c|}{$\begin{array}{l}\text { Phe=phenylalanine. PKU=phenylketonuria. EF=executive function. IQ=intelligence quotient. SES=socioeconomic status. Evidence included for target Phe concentrations during } ¥ \text { childhood (<12 years), } \\
\text { *adolescence (12-18 years), and tadulthood ( } \geq 18 \text { years). }\end{array}$} \\
\hline
\end{tabular}

samples. ${ }^{46-48}$ Data from studies investigating neurocognitive outcomes are largely based on plasma phenylalanine concentrations, whereas routine practice is dried blood spots measurements. The guideline statements here on phenylalanine targets present the upper target phenylalanine concentrations, whereas the published work discusses means or medians. Consequently, the guideline statements are stricter than study findings. However, this difference might also compensate for other factors, such as dried blood spots instead of plasma phenylalanine concentrations, and not testing blood phenylalanine after an overnight fast, which is usually the highest point in 24 h. ${ }^{49,50}$ We advise that blood phenylalanine samples are taken at the same time of day and under the same nutritional conditions in each individual patient.

Other markers, such as the phenylalanine-to-tyrosine ratio or the variation in the phenylalanine concentration, could be of additional value, ${ }^{41,51-55}$ but any advantage offered in addition to blood phenylalanine measurements still remains to be determined, particularly as tyrosine concentrations vary considerably throughout 24 h. ${ }^{49,56}$

\section{Practical issues in dietary and $\mathrm{BH} 4$ treatment}

Dietary phenylalanine restriction is the mainstay of treatment. This treatment consists of three parts: natural protein restriction using individual phenylalanine tolerance, ${ }^{57}$ phenylalanine-free L-aminoacid supplements (usually with added vitamins and minerals) to meet protein and non-protein requirements, and low protein food to meet energy requirements. Although we have longstanding experience with dietary treatment, it is only since the 2008 introduction of sapropterin dihydrochloride that more of our treatment is evidencebased rather than experience-based, but important evidence gaps still exist in several areas. Patients with the most severe PAH deficiency usually tolerate a daily intake of less than $350 \mathrm{mg}$ phenylalanine, and therefore the quality of aminoacid supplements is important. Total protein intake should supply the age-related safe levels of protein intake (FAO/WHO/UNU 2007) with an additional $40 \%$ of L-aminoacids, given as natural protein or supplements according to $\mathrm{FAO} / \mathrm{WHO} / \mathrm{UNU}$, using ideal bodyweight to calculate the dose ([(ideal bodyweight $[\mathrm{kg}] \times 0 \cdot 8)$-intake of natural protein $(\mathrm{g})] \times 1 \cdot 4=$ dose $[\mathrm{g}])$. This calculation encompasses an additional $20 \%$ of L-aminoacids to compensate for the so-called digestible indispensable aminoacid score and a further $20 \%$ of L-aminoacids to optimise the effect of L-aminoacids on blood phenylalanine control. If inadequate doses of L-aminoacids are given, these aminoacids become ratelimiting for protein synthesis, and protein metabolism becomes catabolism. In net protein catabolism, phenylalanine will not only remain unused for protein synthesis, but will also be released, and the concentration will increase. Therefore, giving L-aminoacids decreases the blood phenylalanine concentration.

Aminoacid supplements can cause gastrointestinal upset (abdominal pain, diarrhoea, and constipation) in young children. ${ }^{58}$ In adult patients, life-long and higher intake of aminoacid supplements has been linked to proteinuria and decreased glomerular filtration rate. ${ }^{59}$ Aminoacid supplements should be evenly administered,
For more on the FAO/WHO/ UNU 2007 report see http://apps.who.int/iris/ bitstream/10665/43411/1/ WHO_TRS_935_eng.pdf?ua $=1$ 
at least three times throughout the day, to minimise fluctuations in blood phenylalanine variability. ${ }^{50}$

Low protein foods should contain $50 \mathrm{mg}$ of phenylalanine or less per $100 \mathrm{~g}$ (equivalent to $1 \mathrm{~g}$ of protein per $100 \mathrm{~g}$ ) of dry product. Fruit and vegetables (excluding potatoes) containing less than $75 \mathrm{mg}$ of phenylalanine per $100 \mathrm{~g}$ of food product should not adversely affect blood phenylalanine control and can be included without restriction in the diet. ${ }^{60}$

The optimal amount of tyrosine provided in a low phenylalanine diet is unknown, but additional supplementation in excess of amounts provided by aminoacid supplements is not associated with a benefit. ${ }^{61}$ At present, no statement can be given regarding daily practice with reference to supplementation of large neutral aminoacids treatment (figure 2) or the use of glycomacropeptide because of insufficient evidence.

As illness and fever cause increased catabolism and higher blood phenylalanine concentrations, aminoacid supplements and energy requirements should be met during infection. Antipyretics or analgesics, such as paracetamol and ibuprofen, should be considered to control temperature and improve appetite.

Aspartame (E951) is an intense sweetener composed of $50 \%$ phenylalanine, ${ }^{62,63}$ and needs to be avoided in patients with PKU. In neotame, a similar artificial sweetener to aspartame, phenylalanine content is comparable but bioavailability is largely reduced. ${ }^{64}$ Some medications contain aspartame (such as antibiotics), and short treatment courses might need to be given if no alternatives are readily available.

Patients with PKU, especially with a higher residual $\mathrm{PAH}$ activity, might respond to $\mathrm{BH} 4$ administration with a significant increase in phenylalanine tolerance, or decrease in blood phenylalanine concentrations, or both. ${ }^{65-67}$ All patients warrant testing for $\mathrm{BH} 4$ responsiveness either by genotyping or $\mathrm{BH} 4$ loading. ${ }^{68}$ According to the group's consensus, in any patient without two known null mutations for PKU or two known BH4 responsive mutations, a $48 \mathrm{~h} \mathrm{BH} 4$ loading test should be done by analysing the blood phenylalanine concentrations before and after a single daily dose ( $20 \mathrm{mg} / \mathrm{kg}$ per day) on two consecutive days. ${ }^{68}$ In the neonatal period, to avoid delays in dietary treatment, a $24 \mathrm{~h}$ instead of $48 \mathrm{~h} \mathrm{BH} 4$ loading test is advised before starting the diet. Treatment with BH4 should only be prescribed in cases of proven long-term BH4 responsiveness, defined as an increase in the amount of natural protein of $100 \%$ or more or improved biochemical control (phenylalanine $>75 \%$ in target range) and proven by a trial (of up to 6 months) of treatment with BH4. The treatment trial starts at $10-20 \mathrm{mg}$ of $\mathrm{BH} 4$ per $\mathrm{kg}$ bodyweight and natural protein intake is increased (with the advice of a dietician), the BH4 dose is adjusted, and the aminoacid supplements are decreased accordingly, while blood phenylalanine concentrations are still maintained in the target range. BH4 treatment should be stopped if blood phenylalanine concentrations are consistently above the upper target range, with a lack of response to an increase in $\mathrm{BH} 4$ dose. If nutritional status deteriorates (eg, development of obesity or nutritional deficiencies), discontinuation of $\mathrm{BH} 4$ treatment should be discussed. BH4 treatment can be given during pregnancy, but only if women are known to be $\mathrm{BH} 4$ responders and dietary treatment alone is unsuccessful.

\section{Follow-up and adherence}

Treatment and follow-up of patients should be done in specialised metabolic centres, with at least an experienced metabolic physician and dietician for both children and adults, and a specialised metabolic laboratory. Establishing adult metabolic teams and centres to care for and monitor older patients with PKU is important. Ideally, these teams will be led by an adult metabolic disease physician who can coordinate care and liaise with different specialties as necessary. Access to a neuropsychologist, or psychologist, and a social worker is strongly advised, but this advice is on the basis of clinical rather than evidence-based practice.

Follow-up includes home blood sampling and outpatient visits, the frequency of both being largely dependent on age (table 2). Various life events, such as change of school, starting work, and living independently, as well as adherence issues (eg, during adolescence) might necessitate a higher frequency of blood phenylalanine testing or visits. The transition process not only includes the transition of patients from paediatric to adult care, but also the transition of the responsibility for treatment from parents to the patient. The pathway to greater autonomy generally starts at around 12 years with progression to adult services from the age of 16 years.

Outpatient visits include taking a medical and dietary history, collecting anthropometric data, such as body mass index, undertaking a physical and neurological examination, especially observing for clinical signs of phenylalanine toxicity and nutrient (including phenylalanine) deficiency, ${ }^{69,70}$ and discussing issues of treatment and outcome (such as neurological and psychiatric issues, behaviour, and mood). Table 2 lists the additional investigations necessary, and these focus on potential nutritional deficiencies (especially iron and vitamin $\left.B_{12}\right),{ }^{71-74}$ neurocognitive measures, and bone mineral density. Clinical symptoms of nutrient deficiency are rare and are mostly described because of vitamin $B_{12}$ deficiency (if micronutrient supplementation, which is usually added to aminoacid supplements, is stopped or partially taken, alongside a meat-free diet). ${ }^{73,74}$ The incidence of osteopenia and osteoporosis in PKU is somewhat higher than in the general population, but only one study indicated that increased risk of fractures exists. ${ }^{5,75,76}$ Follow-up is advised with dual-energy $\mathrm{x}$-ray absorptiometry scanning once during late adolescence. If normal, a repeat scan is unnecessary. If abnormal, repetition with or without a change of treatment should follow after 1 year. Additionally, micronutrient deficiencies (selenium, zinc, coenzyme Q10, and 
L-carnitine) have been linked to oxidative stress in PKU, ${ }^{7}$ and oxidative stress is associated with poor metabolic control. ${ }^{44}$ However, because of the lack of clinical symptoms associated with oxidative stress, and the absence of increased oxidative stress with adequate metabolic control, we do not propose routine biochemical monitoring of oxidative stress.

Routine neurocognitive assessments should be done at ages 12 years and 18 years in all patients, since blood phenylalanine treatment targets and life-phase changes occur at these ages (including change of school, living situation, starting work, and becoming an adult). We also advise measurement of quality of life and discussion of psychosocial functioning during clinic visits with PKU-specific health-related quality of life instruments. ${ }^{30,31}$

To achieve long-term adherence, changing the attitude and motivation of the patient might be more effective than improving knowledge. ${ }^{78}$ Regular professional health support might be needed throughout life to encourage normal, healthy feeding behaviours, with a positive acceptance of a low phenylalanine diet.

As health-care providers have a legal obligation to protect and care for each child in their care, the following considerations are proposed when a child $(<12$ years of age) is in poor metabolic control. When more than $50 \%$ of the phenylalanine concentrations are out of the target range during a period of 6 months (approximately 13 measurements per year), health-care providers should consider increased frequency of blood phenylalanine monitoring and outpatient visits, and re-education, plus psychology consultation or social worker interventions, and hospital admission. When around $100 \%$ of measured blood phenylalanine concentrations are out of the target range during a period of 6 months and other signs of failure of adherence; safety issues; or lack of cooperation, clinic non-

\begin{tabular}{|c|c|c|c|c|}
\hline & Childhood (<12 years) & Adolescence (12-18 years) & $\begin{array}{l}\text { Adulthood ( } \geq 18 \text { years), excluding } \\
\text { maternal PKU }\end{array}$ & Maternal PKU \\
\hline Outpatient visit & $\begin{array}{l}\text { Every } 2 \text { months at age } 0-1 \text { years and } \\
\text { twice per year at age } 1-12 \text { years given } \\
\text { good clinical and metabolic control; } \\
\text { extra clinic visit as indicated }\end{array}$ & $\begin{array}{l}\text { Twice per year given good clinical and } \\
\text { metabolic control; extra clinic visit as indicated }\end{array}$ & $\begin{array}{l}\text { Once per year given good clinical and } \\
\text { metabolic control; extra clinic visit as } \\
\text { indicated }\end{array}$ & $\begin{array}{l}\text { Once during each trimester given } \\
\text { good clinical and metabolic control; } \\
\text { extra clinic visit as indicated }\end{array}$ \\
\hline $\begin{array}{l}\text { Clinical nutritional } \\
\text { assessment }\end{array}$ & $\begin{array}{l}\text { Dietary assessment ( } 3 \text { day food record } \\
\text { or } 24 \mathrm{~h} \text { recall), anthropometric } \\
\text { parameters (weight, height, BMI), and } \\
\text { clinical features of micronutrient and } \\
\text { Phe deficiency (especially anorexia, } \\
\text { listlessness, alopecia, and perineal rash) } \\
\text { at every outpatient visit }\end{array}$ & $\begin{array}{l}\text { Dietary assessment ( } 3 \text { day food record or } 24 \mathrm{~h} \\
\text { recall), anthropometric parameters (weight, } \\
\text { height, BMI), and clinical features of } \\
\text { micronutrient and Phe deficiency at every } \\
\text { outpatient visit }\end{array}$ & $\begin{array}{l}\text { Dietary assessment ( } 3 \text { day food record or } \\
24 \mathrm{~h} \text { recall), anthropometric parameters } \\
\text { (weight, height, BMI), and clinical } \\
\text { features of micronutrient and Phe } \\
\text { deficiency every } 12-24 \text { months }\end{array}$ & $\begin{array}{l}\text { Dietary assessment ( } 3 \text { day food } \\
\text { record or } 24 \mathrm{~h} \text { recall) and weight at } \\
\text { every outpatient visit }\end{array}$ \\
\hline $\begin{array}{l}\text { Metabolic control } \\
\text { assessment }\end{array}$ & $\begin{array}{l}\text { Weekly Phe at age } 0-1 \text { year and } \\
\text { fortnightly Phe at age } 1-12 \text { years; } \\
\text { increased frequency as indicated. } \\
\text { Plasma aminoacids annually }\end{array}$ & $\begin{array}{l}\text { Monthly Phe. Increased frequency as indicated; } \\
\text { plasma aminoacids annually }\end{array}$ & $\begin{array}{l}\text { Monthly Phe. Increased frequency as } \\
\text { indicated; plasma aminoacids annually }\end{array}$ & $\begin{array}{l}\text { Pre-conceptionally: weekly } \\
\text { Pregnancy: twice weekly; increased } \\
\text { frequency as indicated } \\
\text { Pre-conceptionally: plasma } \\
\text { aminoacids }\end{array}$ \\
\hline $\begin{array}{l}\text { Biochemical } \\
\text { nutritional } \\
\text { assessment }\end{array}$ & $\begin{array}{l}\text { Annual measurement of plasma } \\
\text { homocysteine or methylmalonic acid, } \\
\text { or both, haemoglobin, mean } \\
\text { corpuscular volume, and ferritin; all } \\
\text { other micronutrients (vitamins and } \\
\text { minerals including calcium, zinc, and } \\
\text { selenium) or hormones (parathyroid } \\
\text { hormone) if clinically indicated }\end{array}$ & $\begin{array}{l}\text { Annual measurement of plasma homocysteine } \\
\text { or methylmalonic acid, or both, haemoglobin, } \\
\text { mean corpuscular volume, and ferritin; all } \\
\text { other micronutrients (vitamins and minerals } \\
\text { including calcium, zinc, and selenium) or } \\
\text { hormones (parathyroid hormone) if clinically } \\
\text { indicated }\end{array}$ & $\begin{array}{l}\text { Annual measurement of plasma } \\
\text { homocysteine or methylmalonic acid, or } \\
\text { both, haemoglobin, mean corpuscular } \\
\text { volume, and ferritin; all other } \\
\text { micronutrients (vitamins and minerals } \\
\text { including calcium, zinc, and selenium) or } \\
\text { hormones (parathyroid hormone) if } \\
\text { clinically indicated }\end{array}$ & $\begin{array}{l}\text { Folic acid, vitamin B12, plasma } \\
\text { homocysteine or methylmalonic acid, } \\
\text { or both, ferritin, full blood count } \\
\text { assessed pre-conceptionally and at } \\
\text { the start of pregnancy; assess when } \\
\text { indicated during pregnancy }\end{array}$ \\
\hline Bone density & $\begin{array}{l}\text { BMD measurement only indicated when } \\
\text { there are specific clinical reasons or } \\
\text { when patients are known to be at } \\
\text { particular risk of metabolic bone disease }\end{array}$ & $\begin{array}{l}\text { First BMD measurement should be done } \\
\text { during late adolescence; when BMD is } \\
\text { abnormal, the measurement (with or without } \\
\text { change of treatment) should be repeated after } \\
1 \text { year; if the results are still low but stable, } \\
\text { yearly BMD is unnecessary. When BMD is } \\
\text { normal, no repeat measurement is necessary; } \\
\text { further study need only be considered when } \\
\text { clinical reasons exist to do so }\end{array}$ & $\begin{array}{l}\text { BMD measurement only indicated when } \\
\text { specific clinical reasons exist or when } \\
\text { patients are known to be at particular } \\
\text { risk of metabolic bone disease }\end{array}$ & Not indicated \\
\hline $\begin{array}{l}\text { Neurocognitive } \\
\text { examination }\end{array}$ & $\begin{array}{l}\text { Neurocognitive testing only when } \\
\text { indicated }\end{array}$ & $\begin{array}{l}\text { Testing at age } 12 \text { years. Proposed domains of } \\
\text { testing for Phe toxic effects are IQ, perception } \\
\text { or visuospatial functioning, EF (divided into } \\
\text { inhibitory control, working memory, and } \\
\text { cognitive flexibility), and motor control. Extra } \\
\text { neurocognitive tests as indicated }\end{array}$ & $\begin{array}{l}\text { Testing at age } 18 \text { years. Proposed } \\
\text { domains of testing for Phe toxic effects } \\
\text { are IQ, perception or visuospatial } \\
\text { functioning, EF (divided into inhibitory } \\
\text { control, working memory, and cognitive } \\
\text { flexibility), and motor control. Extra } \\
\text { neurocognitive tests as indicated }\end{array}$ & Not indicated \\
\hline
\end{tabular}




\begin{tabular}{|c|c|c|c|c|}
\hline & Childhood (<12 years) & Adolescence (12-18 years) & $\begin{array}{l}\text { Adulthood ( } \geq 18 \text { years), excluding } \\
\text { maternal PKU }\end{array}$ & Maternal PKU \\
\hline \multicolumn{5}{|c|}{ (Continued from previous page) } \\
\hline $\begin{array}{l}\text { Adaptive issues } \\
\text { function } \\
\text { examination } \\
\text { (eg, clinically } \\
\text { relevant } \\
\text { behavioural } \\
\text { problems) }\end{array}$ & $\begin{array}{l}\text { Annual clinical assessment or } \\
\text { discussion }\end{array}$ & $\begin{array}{l}\text { Annual clinical assessment or discussion; } \\
\text { screening at age } 12 \text { years }\end{array}$ & $\begin{array}{l}\text { Annual clinical assessment or discussion; } \\
\text { screening at age } 18 \text { years }\end{array}$ & Not indicated \\
\hline $\begin{array}{l}\text { Neurological } \\
\text { examination }\end{array}$ & If neurodegeneration occurs & If neurodegeneration occurs & Annual clinical examination & Not indicated \\
\hline $\begin{array}{l}\text { Investigations of } \\
\text { psychosocial } \\
\text { functioning and } \\
\text { wellbeing, and } \\
\text { health-related } \\
\text { quality of life }\end{array}$ & $\begin{array}{l}\text { Annual clinical assessment or } \\
\text { discussion; once during childhood: } \\
\text { PKU-specific quality of life } \\
\text { questionnaire }\end{array}$ & $\begin{array}{l}\text { Annual clinical assessment or discussion; once } \\
\text { during adolescence: PKU-specific quality of life } \\
\text { questionnaire }\end{array}$ & $\begin{array}{l}\text { Annual clinical assessment or discussion; } \\
\text { once during adulthood PKU-specific } \\
\text { quality of life questionnaire }\end{array}$ & $\begin{array}{l}\text { Additional support might be required } \\
\text { for women who are unable to } \\
\text { conceive }\end{array}$ \\
\hline $\begin{array}{l}\text { Psychiatric } \\
\text { examination }\end{array}$ & $\begin{array}{l}\text { At onset of symptoms of psychiatric } \\
\text { disturbances }\end{array}$ & $\begin{array}{l}\text { At onset of symptoms of psychiatric } \\
\text { disturbances }\end{array}$ & $\begin{array}{l}\text { At onset of symptoms of psychiatric } \\
\text { disturbances }\end{array}$ & Not indicated \\
\hline $\begin{array}{l}\text { Neuroimaging } \\
\text { examination (MRI) }\end{array}$ & $\begin{array}{l}\text { When there is an unexpected clinical } \\
\text { course and/or unexpected neurological } \\
\text { deficits }\end{array}$ & $\begin{array}{l}\text { When there is an unexpected clinical course } \\
\text { and/or unexpected neurological deficits }\end{array}$ & $\begin{array}{l}\text { When there is an unexpected clinical } \\
\text { course and/or unexpected neurological } \\
\text { deficits }\end{array}$ & Not indicated \\
\hline $\begin{array}{l}\text { Investigations } \\
\text { specific to age } \\
\text { group }\end{array}$ & .. &.. & .. & $\begin{array}{l}\text { Ultrasound at } 18-22 \text { weeks of } \\
\text { pregnancy with screening for organ } \\
\text { development (especially if a lack of } \\
\text { optimal metabolic control exists); } \\
\text { echocardiogram in all infants who are } \\
\text { conceived by women with either high } \\
\text { blood Phe concentrations or poor } \\
\text { maternal blood Phe control during } \\
\text { pregnancy }\end{array}$ \\
\hline
\end{tabular}

attendance, or unresolved issues outside PKU, are also apparent, health-care providers should consider consultation with social services and child safeguarding measures. These proposals are based on the Delphi consensus method and are suggested in order to improve the outcome of patients from families who are resistant to routine advice and commonly fail to engage successfully with health professionals.

\section{Special conditions}

Within treatment for PKU, some specific conditions require a very specific treatment strategy. These groups include maternal PKU and late diagnosed or untreated PKU. Treatment for women with PKU also aims to prevent fetal effects of high maternal phenylalanine concentrations, called maternal PKU syndrome. ${ }^{79}$ Blood phenylalanine concentrations should ideally be kept between $120 \mu \mathrm{mol} / \mathrm{L}$ and $360 \mu \mathrm{mol} / \mathrm{L}$ from preconception onwards. ${ }^{80-84}$ Maintaining these concentrations necessitates continuous education throughout preadolescence, adolescence, and adulthood. ${ }^{85}$ Contraceptive strategies should only be discontinued after stable phenylalanine concentrations within the target range have been achieved for at least 2 weeks, thus preventing sustained phenylalanine concentrations above or below the target range. ${ }^{86}$ phenylalanine intake must immediately be increased by 50-100 mg per day when blood phenylalanine is $120 \mu \mathrm{mol} / \mathrm{L}$ or less at anytime during pregnancy. However, no treatment is necessary if untreated blood phenylalanine concentrations are less than $360 \mu \mathrm{mol} / \mathrm{L} .{ }^{87-89}$ Stable weight gain during pregnancy improves outcome, ${ }^{90,91}$ and energy intake should be monitored to ensure it is adequate but not excessive.

Referral to a fertility centre should be considered for patients with well controlled phenylalanine concentrations who do not conceive within 6 months. Women with an unplanned pregnancy should be seen within $24 \mathrm{~h}$ to initiate immediate dietary treatment. Treatment will require intensive intervention-eg, consider the use of the support of a home "Resource Mother" ${ }^{45,92}$ (available in the USA) or even hospital admission. ${ }^{93}$ Treatment might be difficult because of nausea, which can necessitate dietary adjustments such as small and frequent low protein meals and snacks, ${ }^{94}$ tube feeding, safe antiemetic therapy, and acid-reducing medications.

Blood phenylalanine concentration should be checked at least once weekly before pregnancy and at least twice 
weekly during pregnancy. This check requires a rapid laboratory turnaround time. High blood phenylalanine concentrations above target range (120-360 $\mu \mathrm{mol} / \mathrm{L})$ imply a high-risk pregnancy, necessitating the need for a fetal ultrasound at 18-22 weeks of pregnancy with screening for organ development (depending on the country, as for some countries this scan is an additional scan).

Aminoacid supplements usually supply sufficient tyrosine (intake should be at least $6 \mathrm{~g}$ per day). We advise $400 \mu \mathrm{g}$ per day of folic acid preconceptually and during the first 12 weeks of pregnancy, which corresponds with general antenatal recommendations.

We encourage breastfeeding and do not consider there to be contraindications for breastfeeding in maternal PKU, but clinical experience would suggest that the provision of breast feeding to an infant with PKU whose mother also has PKU requires careful monitoring with regard to the phenylalanine concentrations both in the mother and the infant.

Patients with PKU who are diagnosed late or patients with untreated PKU, especially because of newborn screening failures or lack of newborn screening or treatment (eg, immigrants), also need special consideration..$^{95-97}$ Patients with PKU who are diagnosed late can improve their IQ with treatment, ${ }^{97-99}$ and improvements in seizures and behaviour can occur in patients with untreated PKU. ${ }^{99}$ Therefore, regardless of age, we advise the identification of these patients. Treatment for patients with a late diagnosis of PKU should always be considered, whereas in patients with untreated PKU, introduction of treatment is on an individual basis. If treatment is started, a treatment trial of 6 months should be given before the outcomes are assessed (including motor function [less tremors or spasticity] and behaviour [less restless and irritable, more alert or responsive, and less aggressive with decreased frequency and severity of self-injury behaviours]), but further data are required to give clear recommendations for the care of late diagnosed or untreated PKU.

\section{Conclusion and future directions}

To set a standard of care for all patients with PKU in Europe, we have developed this first set of European guidelines for the diagnosis and treatment on the basis of the highest quality of available evidence. We have identified knowledge gaps that require further research to direct better care for the future.

Optimisation of all current treatment strategies is essential, with a focus on adult and elderly patients and a definition of their difficulties and any explanatory pathophysiological mechanisms. Such future treatment strategies might target the blood phenylalanine concentrations through the use of phenylalanine ammonia-lyase modified with polyethylene glycol, new chaperones, and gene treatment. ${ }^{100}$ Other treatments might directly affect cerebral metabolism, such as the

\section{Search strategy and selection criteria}

We searched PubMed (MEDLINE), Embase, the NHS Economic Evaluations Database (NEED), the Cochrane Library, and reference lists for relevant publications in English. We used the search terms listed in the appendix. All literature that was reviewed was published up to Dec 31, 2015, and was without any exclusion of publications before a specified year. In total, 975 publications were reviewed. The quality of the studies was assessed by two group members independently, or by group discussion, or both, before we developed the conclusions into recommendations. Recommendations with no or low level of evidence were discussed with all participants during five face-to-face plenary sessions until consensus was reached, in line with the Delphi method. The key recommendations were either based on evidence (if level of evidence was A or B [SIGN method]) or by consensus (Delphi method) if the level of evidence was $\mathrm{C}$ or $\mathrm{D}$, or are so-called good practice points that are not based on any evidence.

use of large neutral aminoacids. Both glycomacropeptide and large neutral aminoacids are already being used in some countries but require further proof of safety and efficacy. ${ }^{101,102}$ We also need to improve the quality of care delivered by some PKU centres, particularly in lowincome and middle-income countries, to achieve acceptable care for all patients with PKU in Europe. ${ }^{8}$

To facilitate attainment of these objectives, the ESPKU and the development of European Reference Networks for PKU are important. Especially for rare diseases, an international consortia to investigate outcomes in relation to treatment strategies would be very useful. The European Reference Network for metabolic diseases, including PKU, is an important international consortium that can facilitate studying outcomes associated with varying treatments options and target phenylalanine concentrations in different age ranges.

The availability of a device for home monitoring might further optimise outcomes, ${ }^{103}$ as a shorter turnaround time to attain blood phenylalanine concentrations could help patients improve phenylalanine control.

\section{Contributors}

FJvS led the project, chaired the plenary discussions, and was the lead writer of the manuscript. AMJvW co-chaired the plenary discussions and was the second lead writer of the manuscript. All other authors contributed in the plenary discussions, and co-wrote and approved the manuscript. FJvS contributed to groups B and E (initiation of treatment [a topic of group E] and methods of measuring phenylalanine [a subtopic of group B]). AMJvW was the project assistant and assisted all working groups in the literature search, selection, and grading of evidence, and processed the data. KA, FF, AM, and JHW were members of working group $\mathrm{A}$ (nutritional treatment and nutritional and biochemical follow-up). AB, JC, SCH, and VL were members of working group B (neurocognitive outcomes including imaging). AMB, SK, and MvR were members of working group $\mathrm{C}$ (psychosocial outcomes and adherence). MG, FM, and FKT were members of working group D (adult and maternal phenylketonuria [PKU], late diagnosed, and untreated $\mathrm{PKU}$ ). AB-Q, NB, and ACM were members of working group 
E (diagnosis of PKU and drugs in PKU). KA worked on the large neutral aminoacids main topic. AB-Q worked on the emerging therapies main topic. $\mathrm{AB}$ and $\mathrm{VL}$ worked on the magnetic resonance imaging main topic. NB worked on the diagnosis, differential diagnosis, genotyping, and BH4 loading test main topics. AMB worked on the psychosocial functioning (including quality of life) and mental health main topics. JC worked on the target phenylalanine levels, biochemical markers, and neurocognitive functioning main topics. FF worked on the bone mineral density, oxidative stress, and biochemical follow-up main topics. MG and FKT worked on the maternal PKU and late diagnosed and untreated PKU main topics. SCH worked on the target phenylalanine levels, biochemical markers, and neurocognitive functioning main topics. SK worked on the frequency of visits and phenylalanine level measurement main topics. AM worked on the dietary treatment main topic and contributed to group D on dietary treatment in maternal PKU and untreated or late-treated adults. FM worked on the adult PKU main topic. ACM worked on the BH4 treatment main topic. MvR worked on the adherence main topic and contributed to group D on untreated or late-treated adults. JHW worked on the parenteral nutrition main topic.

\section{Declaration of interests}

KA has been a member of the European Nutrition Expert Panel (Merck Serono International). AB-Q has received honoraria as a speaker for Nutricia International, Vitaflo International, Merck Serono, and Recordati, and is a member of the European Nutrition Expert Panel (supported by Merck Serono International), the Sapropterin Advisory Board (supported by Merck Serono International and BioMarin), and KAMPER Advisory Board (supported by Merck Serono International, BioMarin). NB has been a member of the Merck Serono and BioMarin and Censa Pharmaceuticals scientific advisory boards for phenylketonuria (PKU), and has received grants and honoraria from Merck Serono and BioMarin. AMB, AB, FF, MG, and ACM have been members of scientific advisory boards for PKU (supported by Merck Serono, BioMarin, and Nutricia International). AMB has received grants from Nutricia International and honoraria from Merck Serono, BioMarin, and Nutricia International. JC and MG have received honoraria as consultants and speakers from Merck Serono and Nutricia International/Danone. FF has received honoraria from BioMarin, Merck Serono, and Nutricia International/Danone. SCH has participated in strategic advisory boards and received consultant and speaker honoraria from Merck Serono, Biomarin, and Nutricia International. SK has received honoraria from Merck Serono and BioMarin. VL has received honoraria as a consultant from Nutricia International. AM has received research funding and honoraria from Nutricia International, Vitaflo International, and Merck Serono, chairs the European Nutrition Expert Panel (supported by Merck Serono International), has been a member of the Sapropterin advisory board (supported by Merck Serono International), is a member of the Advisory Boards Element (Danone-Nutricia), and is a member of the scientific advisory board of Arla Foods International. FM has received consultant and speaker honoraria from Merck Serono, Nutricia International, Vitaflo International, and Arla Foods International, and research grants from Merck Serono. ACM has received research funding from Nutricia International, Vitaflo International, and Merck Serono, and has received honoraria as a speaker from Merck Serono and Arla Foods International. MvR was a member of the European Nutritionist Expert Panel in PKU (supported by Merck Serono International; until 2015), is a member of the ELEMENT (Leading Education in Metabolic Error Nutritional Therapy) steering committee for Nutricia International, and has received grants and fees for educational and research activities from Nutricia International and Orphan Europe. FJvS is a member of scientific advisory boards for PKU and aminoacid defects that are supported by Merck Serono (past), BioMarin, Arla Foods International, SoBi, and Nutricia International, has received research grants from Nutricia International, SoBi, Alexion, and Merck Serono, and honoraria as a consultant and speaker from Merck Serono and Nutricia International/Danone, and honoraria as a speaker from Vitaflo International. FKT has received grants from Vitaflo and honoraria as a speaker from Merck Serono. AMJvW and JHW declare no competing interests.

\section{Acknowledgments}

We received a grant from the European Society for Phenylketonuria and Allied Disorders Treated as Phenylketonuria (ESPKU) so that we were able to appoint a project assistant (AMJvW). The ESPKU had no opportunity to influence the writing process. We gratefully acknowledge the external consultants who contributed to the development of these guidelines. We acknowledge gynaecologist Jerzy Giżewski who actively contributed during one of the group sessions focusing on maternal PKU. Finally, we would like to thank the external reviewers Skadi Beblo, Gerard Berry, Miroslaw Bik-Multanowski, Maureen Cleary, Turgay Coşkun, Hulya Gökmen-Özel, Johannes Häberle, Robin Lachmann, Harvey Levy, Yoshiyuki Okano, Ida Schwartz, Jiri Zeman, and the ESPKU. One group (Working Group D) and one plenary meeting were supported by EXCEMED.

References

1 Loeber JG. Neonatal screening in Europe; the situation in 2004. $J$ Inherit Metab Dis 2007; 30: 430-38.

2 Blau N, van Spronsen FJ, Levy HL. Phenylketonuria. Lancet 2010; 376: $1417-27$.

3 de Groot MJ, Hoeksma M, Blau N, Reijngoud DJ, van Spronsen FJ. Pathogenesis of cognitive dysfunction in phenylketonuria: review of hypotheses. Mol Genet Metab 2010; 99 (suppl 1): S86-89.

4 Feillet F, van Spronsen FJ, MacDonald A, et al. Challenges and pitfalls in the management of phenylketonuria. Pediatrics 2010; 126: 333-41.

5 Enns GM, Koch R, Brumm V, Blakely E, Suter R, Jurecki E. Suboptimal outcomes in patients with PKU treated early with diet alone: revisiting the evidence. Mol Genet Metab 2010; 101: 99-109.

6 Ahring K, Belanger-Quintana A, Dokoupil K, et al. Dietary management practices in phenylketonuria across European centres. Clin Nutr 2009; 28: 231-36.

7 Blau N, Belanger-Quintana A, Demirkol M, et al. Management of phenylketonuria in Europe: survey results from 19 countries. Mol Genet Metab 2010; 99: 109-15.

8 Hagedorn TS, van Berkel P, Hammerschmidt G, Lhotakova M, Saludes RP. Requirements for a minimum standard of care for phenylketonuria: the patients' perspective. Orphanet J Rare Dis 2013; 8: 191.

9 van Spronsen FJ, Burgard P. The truth of treating patients with phenylketonuria after childhood: the need for a new guideline. J Inherit Metab Dis 2008; 31: 673-79.

10 Cabana MD, Kiyoshi-Teo H. The broader picture on guideline adherence. JPEN J Parenter Enteral Nutr 2010; 34: 593-94.

11 Weingarten $\mathrm{S}$. Translating practice guidelines into patient care: guidelines at the bedside. Chest 2000; 118 (suppl 2): 4S-7S.

12 Haberle J, Boddaert N, Burlina A, et al. Suggested guidelines for the diagnosis and management of urea cycle disorders. Orphanet J Rare Dis 2012; 7: 32.

13 Thomason MJ, Lord J, Bain MD, et al. A systematic review of evidence for the appropriateness of neonatal screening programmes for inborn errors of metabolism. J Public Health Med 1998; 20: 331-43.

14 Smith I, Beasley MG, Ades AE. Intelligence and quality of dietary treatment in phenylketonuria. Arch Dis Child 1990; 65: 472-78.

15 Campistol J, Gassio R, Artuch R, Vilaseca MA, Unit PKUF-u. Neurocognitive function in mild hyperphenylalaninemia. Dev Med Child Neurol 2011; 53: 405-08.

16 van Spronsen FJ. Mild hyperphenylalaninemia: to treat or not to treat. J Inherit Metab Dis 2011; 34: 651-56.

17 Weglage J, Pietsch M, Feldmann R, et al. Normal clinical outcome in untreated subjects with mild hyperphenylalaninemia. Pediatr Res 2001; 49: 532-36.

18 Waisbren SE, Noel K, Fahrbach K, et al. Phenylalanine blood levels and clinical outcomes in phenylketonuria: a systematic literature review and meta-analysis. Mol Genet Metab 2007; 92: 63-70.

19 Fonnesbeck CJ, McPheeters ML, Krishnaswami S, Lindegren ML, Reimschisel T. Estimating the probability of IQ impairment from blood phenylalanine for phenylketonuria patients: a hierarchical meta-analysis. J Inherit Metab Dis 2013; 36: 757-66.

20 Azen CG, Koch R, Friedman EG, et al. Intellectual development in 12-year-old children treated for phenylketonuria. Am J Dis Child 1991; 145: 35-39. 
21 Cabalska B, Duczynska N, Borzymowska J, Zorska K, Koslacz-Folga A, Bozkowa K. Termination of dietary treatment in phenylketonuria. Eur J Pediatr 1977; 126: 253-62.

22 Koch R, Burton B, Hoganson G, et al. Phenylketonuria in adulthood: a collaborative study. J Inherit Metab Dis 2002; 25: 333-46.

23 Weglage J, Fromm J, van Teeffelen-Heithoff A, et al. Neurocognitive functioning in adults with phenylketonuria: results of a long term study. Mol Genet Metab 2013; 110 (suppl): S44-48.

24 van Spronsen FJ, Huijbregts SC, Bosch AM, Leuzzi V. Cognitive, neurophysiological, neurological and psychosocial outcomes in early-treated PKU-patients: a start toward standardized outcome measurement across development. Mol Genet Metab 2011; 104 (suppl): S45-51.

25 Daelman L, Sedel F, Tourbah A. Progressive neuropsychiatric manifestations of phenylketonuria in adulthood. Rev Neurol (Paris) 2014; 170: 280-87.

26 Anwar MS, Waddell B, O'Riordan J. Neurological improvement following reinstitution of a low phenylalanine diet after 20 years in established phenylketonuria. BMJ Case Rep 2013; 2013.

27 Rubin S, Piffer AL, Rougier MB, et al. Sight-threatening phenylketonuric encephalopathy in a young adult, reversed by diet. JIMD Rep 2013; 10: 83-85.

28 Bik-Multanowski M, Didycz B, Mozrzymas R, et al. Quality of life in noncompliant adults with phenylketonuria after resumption of the diet. J Inherit Metab Dis 2008; 31 (suppl 2): S415-18.

29 Gassio R, Campistol J, Vilaseca MA, Lambruschini N, Cambra FJ, Fuste E. Do adult patients with phenylketonuria improve their quality of life after introduction/resumption of a phenylalanine-restricted diet? Acta Paediatr 2003; 92: 1474-78.

30 Bosch AM, Burlina A, Cunningham A, et al. Assessment of the impact of phenylketonuria and its treatment on quality of life of patients and parents from seven European countries. Orphanet J Rare Dis 2015; 10: 80.

31 Regnault A, Burlina A, Cunningham A, et al. Development and psychometric validation of measures to assess the impact of phenylketonuria and its dietary treatment on patients' and parents' quality of life: the phenylketonuria-quality of life (PKU-QOL) questionnaires. Orphanet J Rare Dis 2015; 10: 59.

32 Albrecht J, Garbade SF, Burgard P. Neuropsychological speed tests and blood phenylalanine levels in patients with phenylketonuria: a meta-analysis. Neurosci Biobehav Rev 2009; 33: 414-21.

33 Bick U, Ullrich K, Stober U, et al. White matter abnormalities in patients with treated hyperphenylalaninaemia: magnetic resonance relaxometry and proton spectroscopy findings. Eur J Pediatr 1993. 152: $1012-20$

34 Kono K, Okano Y, Nakayama K, et al. Diffusion-weighted MR imaging in patients with phenylketonuria: relationship between serum phenylalanine levels and ADC values in cerebral white matter. Radiology 2005; 236: 630-36.

35 Cleary MA, Walter JH, Wraith JE, et al. Magnetic resonance imaging of the brain in phenylketonuria. Lancet 1994; 344: 87-90.

36 Manara R, Burlina AP, Citton V, et al. Brain MRI diffusion-weighted imaging in patients with classical phenylketonuria. Neuroradiology 2009; 51: 803-12.

37 Diamond A, Prevor MB, Callender G, Druin DP Prefrontal cortex cognitive deficits in children treated early and continuously for PKU. Monogr Soc Res Child Dev 1997; 62: i-v, 1-208.

38 Leuzzi V, Pansini M, Sechi E, et al. Executive function impairmen in early-treated PKU subjects with normal mental development. J Inherit Metab Dis 2004; 27: 115-25.

39 Huijbregts SC, de Sonneville LM, van Spronsen FJ, Licht R, Sergeant JA. The neuropsychological profile of early and continuously treated phenylketonuria: orienting, vigilance, and maintenance versus manipulation-functions of working memory. Neurosci Biobehav Rev 2002; 26: 697-712.

40 Schmidt E, Burgard P, Rupp A. Effects of concurrent phenylalanine levels on sustained attention and calculation speed in patients treated early for phenylketonuria. Eur J Pediatr 1996; 155 (suppl 1): S82-86

41 Jahja R, Huijbregts SC, de Sonneville LM, van der Meere JJ, van Spronsen FJ. Neurocognitive evidence for revision of treatment targets and guidelines for phenylketonuria. J Pediatr 2014 164: 895-99 e2
42 ten Hoedt AE, de Sonneville LM, Francois B, et al. High phenylalanine levels directly affect mood and sustained attention in adults with phenylketonuria: a randomised, double-blind, placebo-controlled, crossover trial. J Inherit Metab Dis 2011; 34: 165-71.

43 Hoeksma M, Reijngoud DI, Pruim J, de Valk HW, Paans AM, van Spronsen FJ. Phenylketonuria: high plasma phenylalanine decreases cerebral protein synthesis. Mol Genet Metab 2009; 96: $177-82$.

44 Sanayama Y, Nagasaka $\mathrm{H}$, Takayanagi $\mathrm{M}$, et al Experimental evidence that phenylalanine is strongly associated to oxidative stress in adolescents and adults with phenylketonuria. Mol Genet Metab 2011; 103: 220-25.

45 Vockley J, Andersson HC, Antshel KM, et al. Phenylalanine hydroxylase deficiency: diagnosis and management guideline. Genet Med 2014; 16: 188-200.

46 Groselj U, Murko S, Zerjav Tansek M, et al. Comparison of tandem mass spectrometry and amino acid analyzer for phenylalanine and tyrosine monitoring-implications for clinical management of patients with hyperphenylalaninemia. Clin Biochem 2015; 48: 14-18.

47 Mo XM, Li Y, Tang AG, Ren YP. Simultaneous determination of phenylalanine and tyrosine in peripheral capillary blood by HPLC with ultraviolet detection. Clin Biochem 2013; 46: 1074-78.

48 Gregory CO, Yu C, Singh RH. Blood phenylalanine monitoring for dietary compliance among patients with phenylketonuria: comparison of methods. Genet Med 2007; 9: 761-65.

49 van Spronsen FJ, van Rijn M, van Dijk T, et al. Plasma phenylalanine and tyrosine responses to different nutritional conditions (fasting/postprandial) in patients with phenylketonuria: effect of sample timing. Pediatrics 1993; 92: 570-73.

50 MacDonald A, Rylance G, Hall SK, Asplin D, Booth IW. Factors affecting the variation in plasma phenylalanine in patients with phenylketonuria on diet. Arch Dis Child 1996; 74: 412-17.

51 Anastasoaie V, Kurzius L, Forbes P, Waisbren S. Stability of blood phenylalanine levels and IQ in children with phenylketonuria. Mol Genet Metab 2008; 95: 17-20.

52 Hood A, Grange DK, Christ SE, Steiner R, White DA. Variability in phenylalanine control predicts IQ and executive abilities in children with phenylketonuria. Mol Genet Metab 2014; 111: 445-51.

53 Vilaseca MA, Lambruschini N, Gomez-Lopez L, et al. Quality of dietary control in phenylketonuric patients and its relationship with general intelligence. Nutr Hosp 2010; 25: 60-66.

54 Luciana M, Sullivan J, Nelson CA. Associations between phenylalanine-to-tyrosine ratios and performance on tests of neuropsychological function in adolescents treated early and continuously for phenylketonuria. Child Dev 2001; 72: 1637-52.

55 Sharman R, Sullivan K, Young R, McGill J. A preliminary investigation of the role of the phenylalanine:tyrosine ratio in children with early and continuously treated phenylketonuria: toward identification of "safe" levels. Dev Neuropsychol 2010; 35: 57-65.

56 van Spronsen FJ, van Dijk T, Smit GP, et al. Large daily fluctuations in plasma tyrosine in treated patients with phenylketonuria. Am J Clin Nutr 1996; 64: 916-21.

57 MacLeod EL, Gleason ST, van Calcar SC, Ney DM. Reassessment of phenylalanine tolerance in adults with phenylketonuria is needed as body mass changes. Mol Genet Metab 2009; 98: 331-37.

58 MacDonald A, Rylance G, Asplin D, Harris G, Booth IW. Abnormal feeding behaviours in phenylketonuria. J Hum Nut Diet 1997; 10: 163-70.

59 Hennermann JB, Roloff S, Gebauer C, Vetter B, von Arnim-Baas A Monch E. Long-term treatment with tetrahydrobiopterin in phenylketonuria: treatment strategies and prediction of long-term responders. Mol Genet Metab 2012; 107: 294-301.

60 Rohde C, Mutze U, Weigel JF, et al. Unrestricted consumption of fruits and vegetables in phenylketonuria: no major impact on metabolic control. Eur J Clin Nutr 2012; 66: 633-38.

61 Webster D, Wildgoose J. Tyrosine supplementation for phenylketonuria. Cochrane Database Syst Rev 2013; 6: CD001507.

62 Humphries P, Pretorius E, Naude H. Direct and indirect cellular effects of aspartame on the brain. Eur J Clin Nutr 2008; 62: 451-62.

63 Trefz F, de Sonneville L, Matthis P, Benninger C, Lanz-Englert B, Bickel H. Neuropsychological and biochemical investigations in heterozygotes for phenylketonuria during ingestion of high dose aspartame (a sweetener containing phenylalanine). Hum Genet 1994; 93: 369-74. 
64 Chattopadhyay S, Raychaudhuri U, Chakraborty R. Artificial sweeteners-a review. J Food Sci Technol 2014; 51: 611-21.

65 Burton BK, Grange DK, Milanowski A, et al. The response of patients with phenylketonuria and elevated serum phenylalanine to treatment with oral sapropterin dihydrochloride (6R-tetrahydrobiopterin): a phase II, multicentre, open-label, screening study. J Inherit Metab Dis 2007; 30: 700-07.

66 Lindegren ML, Krishnaswami S, Reimschisel T, Fonnesbeck C, Sathe NA, McPheeters ML. A systematic review of BH4 (Sapropterin) for the adjuvant treatment of phenylketonuria. JIMD Rep 2013; 8: 109-19.

67 Somaraju UR, Merrin M. Sapropterin dihydrochloride for phenylketonuria. Cochrane Database Syst Rev 2015; 3: CD008005.

68 Anjema K, van Rijn M, Hofstede FC, et al. Tetrahydrobiopterin responsiveness in phenylketonuria: prediction with the 48-hour loading test and genotype. Orphanet J Rare Dis 2013; 8: 103.

69 Donati A, Vincenzi C, Tosti A. Acute hair loss in phenylketonuria. JEADV 2009; 23: 613-15.

70 Pode-Shakked B, Shemer-Meiri L, Harmelin A, et al. Man made disease: clinical manifestations of low phenylalanine levels in an inadequately treated phenylketonuria patient and mouse study. Mol Genet Metab 2013; 110 (suppl): S66-70.

71 Evans S, Daly A, MacDonald J, et al. The micronutrient status of patients with phenylketonuria on dietary treatment: an ongoing challenge. Ann Nutr Metab 2014; 65: 42-48.

72 Lammardo AM, Robert M, Rocha JC, et al. Main issues in micronutrient supplementation in phenylketonuria. Mol Genet Metab 2013; 110 (suppl): S1-5.

73 Hanley WB, Feigenbaum A, Clarke JTR, Schoonheyt W, Austin V. Vitamin B12 deficiency in adolescents and young adults with phenylketonuria. Lancet 1993; 342: 997.

74 Lee P, Smith I, Piesowicz A, Brenton D. Spastic paraparesis after anaesthesia. Lancet 1999; 353: 554.

75 Demirdas S, Coakley KE, Bisschop PH, Hollak CE, Bosch AM, Singh RH. Bone health in phenylketonuria: a systematic review and meta-analysis. Orphanet J Rare Dis 2015; 10: 17.

76 Hansen KE, Ney D. A systematic review of bone mineral density and fractures in phenylketonuria. J Inherit Metab Dis 2014; 37: 875-80.

77 Sitta A, Vanzin CS, Biancini GB, et al. Evidence that L-carnitine and selenium supplementation reduces oxidative stress in phenylketonuric patients. Cell Mol Neurobiol 2011; 31: 429-36.

78 Norris SL, Engelgau MM, Narayan KM. Effectiveness of self-management training in type 2 diabetes: a systematic review of randomized controlled trials. Diabetes Care 2001; 24: 561-87.

79 Lenke RR, Levy HL. Maternal phenylketonuria and hyperphenylalaninemia. An international survey of the outcome of untreated and treated pregnancies. N Engl J Med 1980; 303: 1202-08.

80 Lee PJ, Ridout D, Walter JH, Cockburn F.

Maternal phenylketonuria: report from the United Kingdom Registry 1978-97. Arch Dis Child 2005; 90: 143-46.

81 Levy HL, Guldberg P, Guttler F, et al. Congenital heart disease in maternal phenylketonuria: report from the Maternal PKU Collaborative Study. Pediatr Res 2001; 49: 636-42.

82 Prick BW, Hop WC, Duvekot JJ. Maternal phenylketonuria and hyperphenylalaninemia in pregnancy: pregnancy complications and neonatal sequelae in untreated and treated pregnancies. Am J Clin Nutr 2012; 95: 374-82.

83 Rouse B, Azen C. Effect of high maternal blood phenylalanine on offspring congenital anomalies and developmental outcome at ages 4 and 6 years: the importance of strict dietary control preconception and throughout pregnancy. J Pediatr 2004; 144: 235-39.
84 Widaman KF. Phenylketonuria in children and mothers: genes, environments, behavior. Curr Dir Psychol Sci 2009; 18: 48.

85 Koch R, Trefz F, Waisbren S. Psychosocial issues and outcomes in maternal PKU. Mol Genet Metab 2010; 99 (suppl 1): S68-74.

86 Teissier R, Nowak E, Assoun M, et al. Maternal phenylketonuria: low phenylalaninemia might increase the risk of intra uterine growth retardation. J Inherit Metab Dis 2012; 35: 993-99.

87 Levy HL, Waisbren SE, Lobbregt D, et al. Maternal mild hyperphenylalaninaemia: an international survey of offspring outcome. Lancet 1994; 344: 1589-94.

88 Platt LD, Koch R, Hanley WB, et al. The international study of pregnancy outcome in women with maternal phenylketonuria: report of a 12-year study. Am J Obstet Gynecol 2000; 182: 326-33.

89 Waisbren SE, Azen C. Cognitive and behavioral development in maternal phenylketonuria offspring. Pediatrics 2003; 112: 1544-47.

90 Clark BJ, Cockburn F. Management of inborn errors of metabolism during pregnancy. Acta Paediatr Scand Suppl 1991; 373: 43-52.

91 Matalon KM, Acosta PB, Azen C. Role of nutrition in pregnancy with phenylketonuria and birth defects. Pediatrics 2003; 112: 1534-36.

92 Rohr F, Munier A, Sullivan D, et al. The resource mothers study of maternal phenylketonuria: preliminary findings. J Inherit Metab Dis 2004; 27: 145-55.

93 Maillot F, Cook P, Lilburn M, Lee PJ. A practical approach to maternal phenylketonuria management. J Inherit Metab Dis 2007; 30: 198-201.

94 Maltepe C, Koren G. The management of nausea and vomiting of pregnancy and hyperemesis gravidarum-a 2013 update. J Popul Ther Clin Pharmacol 2013; 20: e184-92.

95 Dan B, Christiaens F, Mewasingh LD, De Laet C, Goyens P. Late-treated phenylketonuria mimicking Angelman syndrome. Am J Med Genet 2001; 104: 345-46.

96 Groselj U, Tansek MZ, Smon A, et al. Newborn screening in southeastern Europe. Mol Genet Metab 2014; 113: 42-45.

97 Trefz F, Maillot F, Motzfeldt K, Schwarz M. Adult phenylketonuria outcome and management. Mol Genet Metab 2011; 104 (suppl): S26-30.

98 Grosse SD. Late-treated phenylketonuria and partial reversibility of intellectual impairment. Child Dev 2010; 81: 200-11.

99 Koch R, Moseley K, Ning J, Romstad A, Guldberg P, Guttler F. Long-term beneficial effects of the phenylalanine-restricted diet in late-diagnosed individuals with phenylketonuria. Mol Genet Metab 1999; 67: 148-55.

100 Longo N, Harding CO, Burton BK, et al. Single-dose, subcutaneous recombinant phenylalanine ammonia lyase conjugated with polyethylene glycol in adult patients with phenylketonuria: an open label, multicentre, phase 1 dose-escalation trial. Lancet 2014; 384: 37-44.

101 Solverson P, Murali SG, Litscher SJ, Blank RD, Ney DM. Low bone strength is a manifestation of phenylketonuria in mice and is attenuated by a glycomacropeptide diet. PLoS One 2012; 7: e45165.

102 Ney DM, Gleason ST, van Calcar SC, et al. Nutritional management of PKU with glycomacropeptide from cheese whey. J Inherit Metab Dis 2009; 32: 32-39.

103 Bilginsoy C, Waitzman N, Leonard CO, Ernst SL. Living with phenylketonuria: perspectives of patients and their families. J Inherit Metab Dis 2005; 28: 639-49. 